\title{
Relationship of Adolescent Reproductive Health Knowledge With Self Adjustments In Puberty Among Boys
}

\author{
Nila Widya Keswara ${ }^{1 *}$, Sulistiyah ${ }^{1}$ \\ ${ }^{I}$ Department of Midwifery, Institute of Health and Science Technology RS dr. Soepraoen, Jl. S. Supriadi no 22, \\ Sukun Malang 65147 tel. (0341) 351275 \\ * Corresponding author \\ E-mail: nilakeswara35@gmail.com
}

\begin{abstract}
Puberty is a process of biological changes that include morphology and physiology that occur very rapidly from childhood to adulthood. The purpose of this study was to determine the relationship between adolescent reproductive health knowledge and self-adjustment in puberty among boys at the Marsudisiwi SDK, Malang. An analytical research method was conduct in this research, with a cross sectional approach. Total Sampling technique was use to get 70 samples. Questionnaire instrument with an ordinal scale was used as instrument to drawn data from respondent. Spearman Rank correlation test show p-value value is 0.236. Because the value is $0.236>0.05$, it can be concluded that $\mathrm{H} 1$ is rejected. There is no relationship between knowledge about adolescent reproductive health and adjustment to puberty. The results of this study can be used as a reference for researching with the same variable targeting respondents at a more mature age level (adolescents) related to reproductive health and puberty in boys.
\end{abstract}

Keywords: Adolescent Reproductive Health, Knowledge, Adjustment, Puberty

\section{INTRODUCTION}

Teenagers are the next generation who will grow and become human beings who have strong personalities and have many abilities and useful skills, therefore teenagers really need to get a good and appropriate education so that their potential will develop properly ${ }^{1}$.

Based on the stages, adolescents experience stages of development which are likely to be related to the environment and surroundings so that the characteristics are divided from early adolescence to late adolescence where at the early adolescence stage they experience several phases, one of which is puberty and in this phase will also experience many changes ${ }^{2}$.

Puberty is a process of biological changes that include morphology and physiology that occur very rapidly from childhood to adulthood ${ }^{3}$. Changes that occur during puberty raise doubts feelings of inadequacy and insecurity resulting in poor behavior, where adolescents should be able to adapt to the changes that occur so that satisfaction with themselves and the environment in reproductive health can be achieved $^{4}$.

Reproductive health is very important to be informed, especially about the problem by health service providers and 
decision makers, and it is also important for education and program organizers for adolescents to help reduce adolescent reproductive health problems.

Puberty Knowledge related to physical changes during female puberty that is most widely known by women as menstruation (89\%) and breast growth $(60 \%)$ mostly known by men. 5 The percentage of physical changes during puberty that most women and men know about is a change in voice, which are $77 \%$ and $53 \%$, respectively. Based on the results of a preliminary study conducted by researchers on November 13, 2019, the results obtained from 132 children from grades 4 to 6 of elementary school as many as 70 boys and 62 girls, most of the 70 children still didn't understand the phase of puberty. .

It is necessary to prepare children with plenty knowledge about the physical changes they will experienced, so that the experience of puberty changes does not become a traumatic experience. ${ }^{6}$ Some Efforts to prepare children to face puberty are influenced by knowledge, attitudes and actions. $^{7}$ The purpose of this study was to determine the relationship between knowledge about adolescent reproductive health and adjustment to face puberty in boys at the Marsudisiwi SDK, Malang City.

\section{METHOD}

This type of research is an analytic study with a cross sectional approach.

The questionnaire about adolescent reproductive health and self-adjustment during puberty was developed by author and has been tested for validity and reliability. Corelative Analytic statistical approach was use to examine relation between two variable.

\section{RESULT}

Some of respondent showed lack adolescent reproductive health knowledge which can affect their adjustment to face puberty.
Knowledge data about adolescent reproductive health and adjustment to face puberty can be seen below:

\section{Adolescence health reproductive knowledge}

Tabel 1. Adolescence health reproductive knowledge

\begin{tabular}{clcc}
\hline No & Criteria & $\begin{array}{c}\text { Frequents } \\
(\mathrm{n})\end{array}$ & $\begin{array}{c}\text { Percentages } \\
(\%)\end{array}$ \\
\hline 1 & Good & 30 & 42.9 \\
2 & Fair & 37 & 52.8 \\
3 & Lack & 3 & 4.3 \\
& Total & 70 & 100 \\
\hline
\end{tabular}

(Source : Primary data, 2020)

According to table above, it is found that most of the respondents have sufficient knowledge, 37 children (52.8\%) and a small proportion of respondents have less/ lack knowledge as many as 3 children (4.3\%).

Adjustment to Facing Puberty.

Tabel 2. Adjustment to Facing Puberty.

\begin{tabular}{clcc}
\hline No & Criteria & $\begin{array}{c}\text { Frequency } \\
\text { (Anak) }\end{array}$ & $\begin{array}{c}\text { Percentages } \\
(\%)\end{array}$ \\
\hline 1 & Good & 4 & 5.7 \\
2 & Fair & 49 & 70 \\
3 & Lack & 17 & 24.3 \\
& Total & 70 & 100 \\
\hline
\end{tabular}

(Source : Primary data , 2020)

According the table above, the results show that most of the respondents were adjusted to the age of puberty enough, namely 49 children $(70 \%)$ and a small proportion of respondents were well adjusted, namely 4 children $(5.7 \%)$.

Tabel 3 Spearman Rho Analytical statistic

\begin{tabular}{lllll}
\hline Var 1 & n & Sig & r & Var 2 \\
\hline Knowledge & 70 & 0.36 & 0.144 & Adjusment
\end{tabular}

* Significance

From the table above, it is known that the $\mathrm{p}$ value is 0.236 . Because the value is $0.236>0.05$, it can be concluded that $\mathrm{H} 1$ is rejected, meaning that there is no relationship between knowledge about adolescent reproductive health and adjustment to puberty. 


\section{DISCUSSION}

Based on table 4.4, it can be seen the results that $\mathrm{H} 1$ is rejected with the conclusion that there is no relationship between adolescent reproductive health knowledge and self adjustment in puberty.

Puberty refers to the process of physical changes by which a child's body becomes an adult body capable of reproduction and it usually happens in the second decade of life. The World Health Organization defined the ages from 10 to 19 as adolescence age. This is a period in which the individual's personality in terms of culture and health is shaped and the maturity in social, physical, and psychological aspects of life happens. Also, the brain and mind potentials reach perfection and make the mental capacities developed.1 Among different levels and periods of growth, adolescence is very important and outstanding because the changes that happen to an adolescent affect family and society as well (Afghari et al., 2008).

Knowledge of the physiology of human reproduction and the means to protect oneself against sexual or reproductive problems and diseases should be available to adolescents. Better knowledge of these subjects among young adults will lead to correct attitudes and responsible reproductive health behavior.

Knowledge is gained in the process of learning and represents the level of awareness. The level of knowledge about puberty includes the amount and quality of relevant information. All children need to be prepared for puberty in time and in an appropriate manner; this should include all associations and contexts related to this stage. Although comprehensive sex education including the issue of puberty should be centred around the family, there is no guarantee that children will gain (provided that sex education does not become taboo) subjectively and socially appropriate information, attitudes and behaviour in the broadest sense of sexual behaviour. Children should learn the required knowledge about puberty before its onset - during pre-puberty when they are in primary school ${ }^{9}$.

Puberty is not a problem to be solved; it is simply a time of accelerated physical growth and sexual development experienced by every human. But by facing this pivotal phase of life unprepared, learners are left confused and unsupported, which in turn affects the quality of their education. Education sector has a large educated workforce that can, if properly trained, provide accurate knowledge and develop a relationship of trust with students. The school setting promotes relationships and social interaction with peers and teachers or other school staff, which can lead to a feeling of school connectedness (the feeling that someone in a young person's school cares about his or her well-being). This factor can have a positive impact on school performance; it can mitigate school drop-out, early sexual initiation, risky sexual activity, violence and substance use. In addition, education can challenge the gendered roles of girls and women, and boys and men, and provide resources and support to alleviate the increased physical and social vulnerability associated with puberty ${ }^{14}$.

The study findings reveal that School aged girls do not have adequate knowledge regarding pubertal changes and they are not well prepared for puberty As puberty brings many changes in the body it can be a stressful period for many girls. Hence a proper education awareness regarding pubertal changes is very much necessary for the pre adolescent girls ${ }^{10}$.

Schools have not been recognized as a key source of information on reproductive health. In a survey of young adults carried out in 1998-1999, less than one-third of the respondents learned about family planning and reproductive health at school ${ }^{11}$.

This is influenced by several factors including age and class, where in this study the age of the respondents was between 1012 years. In this stage, it would be understandable that most of respondent has difficulties to understand the changes 
during puberty period ${ }^{8}$. Junior high school student are at a developmental stage called "Adolescence or Puberty".

Study that conducted in India show that knowledge, attitude and practice regarding pubertal changes may vary between pubertal girls. Variables in parent's education, source of information and birth order has a beneficial effect on better knowledge, attitude and practice among prepubertal girls. concluded that $50 \%$ urban and $25 \%$ tribal adolescents girls were aware about secondary sexual changes during puberty. The difference in the knowledge level of the students about changes during puberty is associated with their source of information. The majority of central board school participants has good attitude towards puberty changes when compared to state and matriculation board study participants ${ }^{13}$.

Other research result suggest that an appropriate educational program including physical and psychological changes, as well as the appropriate nutrition during puberty improves female adolescents' knowledge, attitude, and behavior. To give teenage girls the opportunity to enjoy their youth before becoming a mother, it is necessary to educate them about reproductive health issues ${ }^{12}$

Present study also reveal that health education of puberty increased the adolescents' attitude from a mean score of 26 to 48 . The expected score for attitude was 48 and there was 22 score difference which seems to be a significant change in the participants' attitude. Yong believes that health education for adolescents strongly affects their attitude toward their abilities and suggests that education should be long term enough (at least ten years) to develop their attitude. Poope also showed that educational films improve the adolescents' attitude toward adolescents' relationships and their knowledge about various safe sexual behaviors ${ }^{12}$.

\section{CONCLUSION}

Based from research analysis shown there is no correlation between knowledge of adolescent reproductive health and adjustment to puberty in boys. Age and class was two factors might be contribute in this phenomena. Limited variables and low consideration about confounding variables could be limitation in this study. But in the other hand study provide basic phenomenon that could be analyze in future research with bigger respondent and conduct more variables related to knowledge and self adjustment.

\section{ACKNOWLEDGMENTS}

Thanks are conveyed to colleagues, respondents and all staff of SDK Marsudisiwi Malang City who were very helpful in this research stage.

\section{REFERENCES}

1. Marmi, (2015). Kesehatan Reproduksi. Pustaka Pelajar : Yogyakarta

2. Santoso, S. (2001). Masalah Kesehatan Remaja. Sari Pediatri, Vol. 3, No. 3 : 190 $-198$

3. Al-Mighwar, M. (2006). Psikologi Remaja. Bandung: Pustaka Setia

4. Hurlock, Elizabeth B. (1980). Psikologi Perkembangan: Suatu Pendekatan Sepanjang Rentang Kehidupan. Jakarta : Gramedia

5. SDKI. (2017). Kementrian Kesehatan. Jakarta.

6. Ali, M. dan Asrori, M., (2010). Psikologi Remaja: Perkembangan Peserta Didik. Cetakan ke enam. Jakarta: PT. Bumi Aksara

7. Rahmayanti. (2013). Hubungan Pengetahuan Sikap dan Tindakan Ibu Dengan Upaya Mempersiapkan Masa Pubertas Pada Anak SMP di Desa Keade Aceh Kecamatan Samalanga. Portal 
http://simtakp.stmikubudiyah.ac.id /docjurnal diakses tanggal 25 januari 2014

8. Suryani, Tatik. 2013. Perilaku Konsumen di Era Internet. Yogyakarta: Graha

Ilmu

9. Rašková, Miluše \& Provázková Stolinská, Dominika. (2018). Knowledge About Puberty Among Primary School Children In The Czech Republic. 7790-7796. 10.21125/iceri.2018.0393.

10. Chethana D Poojary et al., American International Journal of Research in Humanities, Arts and Social Sciences, 12(1), SeptemberNovember, 2015, pp. 51-53

11. BPS. (2004). Indonesia Young Adult Reproductive Health Survey 20022003. Badan Pusat Statistik (BPSStatistics Indonesia) Jakarta, Indonesia

12. Afghari, A., Eghtedari, S., Pashmi, R., \& Sadri, G. H. (2008). Effects of puberty health education on 10-14 year-old girls' knowledge, attitude, and behavior. Iranian Journal of Nursing and Midwifery Research, 13(1).

13. Jishala, M., Pavithra, K., Krishnaveni, K., Shanmugasundaram, R., \& Sambathkumarra, M. (2019). Assessing the Source of Knowledge, Attitude and Practice on Pubertal Awareness Among Pre-Pubertal Girls. International Journal of Pharma and Bio Sciences, 9(4), $\quad$ 71-80. https://doi.org/10.22376/ijpbs/lpr.2019. 9.4.p71-80

14. UNESCO. (2014). Puberty Education and Mentsrual Hygiene Management. In Lancet (Vol. 1, Issue 8650). http://creativecommons.org/licenses/bysa/3.0/igo/ 